\title{
Explaining Black-White Differences in College Outcomes at Missouri Public Universities
}

Cory Koedel

Conditional on enrollment at a four-year public university, African American students are less likely to graduate and less likely to graduate with a STEM degree than White students. This article reports on evidence from Missouri showing that these outcome differences in college can be explained entirely by differences in students' academic preparation prior to college enrollment. While this result should not be taken to imply that college-level interventions cannot help to reduce observed college success gaps by race, it does point toward pre-college interventions as being better targeted at their underlying source. (JEL I23, I24, J15)

Federal Reserve Bank of St. Louis Review, First Quarter 2017, 99(1), pp. 77-83. http://dx.doi.org/10.20955/r.2017.77-83

\section{INTRODUCTION}

Racial disparities in college completion rates are large. At just over 40 percent, the sixyear graduation rate for African Americans is over 20 percentage points lower than for Whites nationally (DeAngelo et al. 2011). The completion gap is similar but slightly smaller at public universities (Lynch and Engle, 2010). African Americans are also less likely to complete degrees in science, technology, engineering, and math (STEM; Arcidiacono, Aucejo, and Hotz, 2016; Arcidiacono, Aucejo, and Spenner, 2012; and Sass, 2015) and more generally are disproportionately represented in lower-paying fields among college graduates (Carnevale et al., 2016). These disparities in college outcomes are disconcerting given the substantial earnings premiums associated with college completion and degree attainment in more rigorous fields. Moreover, recent evidence suggests that labor-market returns to a college education are increasing faster over time for African Americans relative to Whites (Long, 2010).

This paper reports on gaps in graduation and STEM degree attainment rates between African American and White students conditional on enrollment at a four-year public university in Missouri. Black-White gaps in these outcomes in Missouri are similar to gaps that have

Cory Koedel is an associate professor of economics and public policy at the University of Missouri, Columbia. This article was prepared for presentation at the symposium, "Does College Level the Playing Field? Racial and Ethnic Differences in Family Wealth Among College-Educated Families," sponsored by the Center for Household Financial Stability and the Research Division of the Federal Reserve Bank of St. Louis, May 25-26, 2016.

( ) 2017, Federal Reserve Bank of St. Louis. The views expressed in this article are those of the author(s) and do not necessarily reflect the views of the Federal Reserve System, the Board of Governors, or the regional Federal Reserve Banks. Articles may be reprinted, reproduced, published, distributed, displayed, and transmitted in their entirety if copyright notice, author name(s), and full citation are included. Abstracts, synopses, and other derivative works may be made only with prior written permission of the Federal Reserve Bank of St. Louis. 
Table 1

Eight-Year Graduation Rates and STEM Attainment Rates by Race and Race-Gender (percent)

\begin{tabular}{lcr} 
& Graduation rate & STEM attainment rate \\
\hline African American & 48.2 & 6.6 \\
\hline White & 63.9 & 11.1 \\
\hline African American female & 51.8 & 4.4 \\
\hline African American male & 42.4 & 10.2 \\
\hline White female & 66.2 & 6.5 \\
\hline White male & 61.1 & 16.7 \\
\hline
\end{tabular}

been documented elsewhere. In the examination of gaps in both outcomes, a key result is that they can be explained entirely by students' academic preparation prior to enrollment in college.

\section{DATA AND SETTING}

The findings reported in this article are based on the analysis of administrative microdata provided by the Missouri Department of Higher Education. A panel covering six cohorts of college students entering the Missouri four-year public university system, which includes 13 campuses in total, was constructed for students who enrolled during the years 1996-2001. The analytic sample is restricted to full-time, state-resident, non-transfer students who entered the public university system as college freshman. ${ }^{1}$ It is further restricted to exclude non-African-American and non-White students. In total, the analysis covers over 60,000 students. African Americans account for 6.3 percent of the sample. In the 2000 U.S. Census, 11.7 percent of Missourians were African American, which is just below the national average of 12.9 percent. See Arcidiacono and Koedel (2014) for more details about the data.

Each student cohort is tracked for eight years to determine graduation and STEMattainment outcomes. Students can be tracked throughout the system over the course of the college career, regardless of transfers, but students who exit the system can no longer be tracked. Students who do not graduate or complete a STEM degree in the system within eight years are treated as non-completers.

The 13 campuses in the Missouri public university system vary in terms of selectivity, urbanicity, and curricular focus. It is also notable that two campuses are historically Black universities, although many White students attend these schools as well. For contextual background see Arcidiacono and Koedel (2014), who provide an overview of the system that includes basic information about campus selectivity, graduation rates, racial diversity of the student body, STEM emphasis, and the geographic location of each university in the state.

\section{RAW OUTCOME DATA}

Table 1 reports graduation rates and STEM-attainment rates for the sample of students described in the previous section, split out by race and race-gender. 
The Black-White graduation gap in Missouri is roughly 16 percentage points, and the STEM attainment gap is 4.5 percentage points. These gaps are quite large, especially relative to the base rates. Splitting the results out by gender reveals particularly low graduation rates for African American men, which, coupled with their lower enrollment rates (not shown-see Arcidiacono and Koedel, 2014), leads to the especially large gender gap in degree attainment among African Americans (also see Aucejo, 2012). Although women have higher graduation rates than men within both races, they have much lower STEM attainment rates.

\section{ANALYSIS OF GAPS}

Arcidiacono and Koedel (2014) develop a modeling framework by which the race-based graduation gaps shown in Table 1 can be decomposed. Here I briefly review the relevant parts of their framework, and their results showing the extent to which students' observable academic preparation prior to college entry can explain graduation rate differences by race. I then extend the modeling approach to examine gaps in STEM attainment.

Arcidiacono and Koedel (2014) model the likelihood of graduation conditional on enrollment as depending on the university attended, $c$, the initial major, $m$ (either STEM or not), and an academic index based on pre-college information, AI. Graduation is further allowed to depend on the cohort, $t$ (where $t=1996,1997, \ldots, 2001$ ). They write the latent utility of graduating (within eight years) for student $i$ as

$$
y_{i}^{*}=\sum_{c} \sum_{m} \sum_{t} I(c, m, t \mid i) \delta_{0 c m t}+\sum_{c} \sum_{m} I(c, m \mid i) A I_{i} \delta_{1 c m}+\varepsilon_{i},
$$

where $I(c, m, t \mid i)$ and $I(c, m \mid i)$ are indicator variables for whether student $i$ attended university $c$ with initial major $m$ and, in the former case, whether $i$ was part of cohort $t$. The academic index enters into equation (1) in a way that allows for differential returns to pre-entry characteristics depending on the university and major. $\varepsilon_{i}$ is an unobserved preference shock. Individuals who graduate, $y_{i}=1$, have latent values greater than zero with $y_{i}=0$ otherwise.

The academic index includes student characteristics and high school indicator variables. Specifically, it includes the student's gender, $f_{i}=1$ if female and zero otherwise; the student's race, $b_{i}=1$ if African American and zero otherwise; the student's ACT math and reading scores, $\operatorname{actm}_{i}$ and $\operatorname{actr}_{i}$, respectively; the student's normalized high school class rank, $g_{i}$; and a vector of high school indicator variables, $\mathbf{h}_{\mathrm{i}}$, where the element that corresponds to the high school student $i$ attended is 1 and the other elements are zero. ${ }^{2}$ The academic index is written as

$$
A I_{i}=\gamma_{0}+\gamma_{1} g_{i}+\gamma_{2} a c t m_{i}+\gamma_{3} a c t r_{i}+\gamma_{4} f_{i}+\gamma_{5} b_{i}+\gamma_{6} f_{i} b_{i}+\mathbf{h}_{\mathbf{i}} \boldsymbol{\theta}
$$

Of particular interest for this article are the coefficients on the race and gender variables, which can be used to determine the likelihood of graduation for African American women and men relative to White women and men, conditional on pre-entry academic preparation and the entering university and major. Note that the coefficients on the race-gender indicators, and all other variables in the academic index, are identified from variation within universityby-major cells. 
Table 2

Index Parameters from Primary and Alternative Specifications for the Index: Graduation Model

\begin{tabular}{lcc} 
& Sparse model & Full model \\
\hline HS class rank & & $13.41(0.043)^{*}$ \\
\hline ACT math & & $0.006(0.003)^{*}$ \\
\hline ACT reading & $0.256(0.036)^{*}$ & $-0.012(0.002)^{*}$ \\
\hline White female & $-0.461(0.084)^{*}$ & $-0.062(0.022)^{*}$ \\
\hline African American male & $-0.089(0.039)^{*}$ & $0.058(0.070)$ \\
\hline African American female & $0.124(0.060)^{*}$ \\
\hline $\begin{array}{l}\text { NOTE: }{ }^{*} \text { indicates statistical significance at the 5 percent level. The full model includes high school fixed effects. These } \\
\text { estimates are taken directly from Table 2 of Arcidiacono and Koedel (2014). }\end{array}$ \\
\hline
\end{tabular}

In addition to reporting on the Arcidiacono and Koedel (2014) findings for graduation outcomes, I extend the modeling approach described by equations (1) and (2) to examine STEM attainment. Because the likelihood of attaining a STEM degree is very small for students who do not initially choose a STEM major (in the Missouri data, less than 3 percent of students who initially enroll in a non-STEM field complete a STEM degree), I restrict the analysis of STEM attainment to students who initially enroll in a STEM major.

\section{FINDINGS}

Table 2 replicates estimates from Table 2 of Arcidiacono and Koedel (2014). The table shows logit coefficients corresponding to the index covariates from two versions of the model described in equations (1) and (2) (the coefficients on the high school indicator variables are suppressed). In column 1 the academic index is reduced to include only the race-gender indicators. Thus, the coefficients indicate differences in graduation rates between African American and White students conditional on the initial university and major but not on the measures of academic preparation. White men are the omitted race-gender group, which means that the coefficients for the other race-gender groups are estimated relative to White men. In column 2, students' class ranks, high school indicators, and ACT math and reading scores are added to the model.

The claim that the entirety of the gap in graduation outcomes between African American and White students can be explained by observable measures of pre-entry academic preparation is supported by the reversal of the Black-White gaps implied by the race-gender coefficients going from column 1 to column 2 of the table. That is, in column 1 African American students are substantially less likely to graduate than White students, within genders, but in column 2 this is no longer the case. African American men are no less likely to graduate than White men conditional on information about the high school, class rank, and ACT scores. African American women are more likely to graduate than White women after accounting for pre-entry academic preparation. 
Table 3

Index Parameters from Primary and Alternative Specifications for the Index: STEM Attainment

\begin{tabular}{lcc} 
& Sparse model & Full model \\
\hline HS class rank & & $15.39(1.82)^{*}$ \\
\hline ACT math & & $0.096(0.013)^{*}$ \\
\hline ACT reading & $-0.190(0.154)$ & $-0.010(0.005)^{*}$ \\
\hline White female & $-0.265(0.222)$ & $-0.479(0.072)^{*}$ \\
\hline African American male & $-0.461(0.381)$ & $0.244(0.153)$ \\
\hline African American female & $-0.491(0.180)^{*}$ \\
\hline NOTE: ${ }^{*}$ indicates statistical significance at the 5 percent level. The full model includes high school fixed effects. \\
\hline
\end{tabular}

To expand on the findings in Table 2, I also perform an out-of-sample prediction exercise for African American students using these data. First, I estimate the full model shown in equations (1) and (2) using data only for White students in the sample, with appropriate adjustments. ${ }^{3}$ Then, using the model trained on White students, I predict the graduation rate for African American students. Consistent with the conditional gaps favoring African Americans within genders in Table 2, the model predicts that African American students outperform observationally similar White student by 2.5 percentage points on average, or approximately 5 percent of the baseline graduation rate.

Next, Table 3 provides analogous results where I follow the same estimation procedure but restrict the sample to students who initially pursue a STEM degree and change the outcome to STEM degree attainment. I restrict the sample to initial STEM entrants because, as noted above, few individuals who start in a non-STEM major ultimately complete a STEM degree.

Just over 20 percent of students in the sample initially enrolled as a STEM major (approximately 13,000 students). African Americans are essentially evenly represented among initial STEM entrants, with STEM entrants accounting for 21 percent of African American enrollment. However, noting that STEM entrants tend to have stronger academic qualifications on average systemwide, African Americans are conditionally overrepresented in STEM at entry. As one illustration of the overrepresentation, Arcidiacono and Koedel (2014) consider a counterfactual sorting scenario where African American students sort to colleges and majors like observationally similar White students. They find that African American representation in STEM at entry would fall from 21 percent to 16 percent under the counterfactual (see Appendix $\mathrm{C}$ of their paper).

The results in Table 3 are much more noisily estimated than those in Table 2 but display a similar pattern for STEM attainment gaps by race. In particular, the sparse model suggests lower STEM attainment rates conditional on STEM entry for African American students relative to White students, but the gaps improve substantially once the measures of pre-entry academic preparation are included (again, within genders). For men, conditional on pre-entry 
academic preparation, African Americans are suggestively more likely to complete a STEM degree than Whites (the estimate in Table 3 is marginally insignificant at the 10 percent level); for women, the conditional difference between African Americans and Whites is essentially zero. These results are substantively similar to recent, related findings from Florida (Sass, 2015).

The large conditional differences in STEM attainment by gender for both races are also notable, especially because the analysis conditions on individuals who initially choose a STEM field, but the gender gaps are outside of the scope of the present article.

\section{DISCUSSION AND CONCLUSION}

This article documents differences in graduation and STEM attainment outcomes between African American and White students attending Missouri four-year public universities. The data come from six cohorts of students entering the Missouri system between 1996 and 2001. The Black-White gap in the college graduation rate in Missouri, conditional on initial enrollment at a four-year public university, is in line with national data from other public colleges at around 16 percentage points (Lynch and Engle, 2010). There is also a significant BlackWhite gap in STEM attainment.

A key finding this article aims to highlight is that observed gaps in college outcomes between African American and White students can be explained entirely by measures of pre-entry academic preparation. This finding, and its policy implications, shares much in common with related work by Cameron and Heckman (2001) on the determinants of college attendance. These authors argue for deeper investments in early human capital development to combat race-based gaps in educational attainment. While it may seem intuitive to intervene at the point where the gaps in key outcomes of interest are observed-in this case, in collegepre-college interventions appear to be much better targeted at the underlying source of racial gaps in the measures of college success considered here. 


\section{NOTES}

1 A small number of students who enter a university with sophomore status but no prior university experience are also included. These are students who have collected a full year's worth of college credits while in high school.

2 Students from high schools from which fewer than five students are observed over the course of the data panel as full-time, non-transfer college entrants are omitted. Only a small number of observations are dropped from the analytic sample for this reason.

3 For example, there is no need for a race indicator in the model. This exercise also requires a small adjustment to the analytic sample; namely, I drop some high schools from which very few white students matriculated to college.

\section{REFERENCES}

Arcidiacono, Peter; Aucejo, Esteban and Hotz, V. Joseph. "University Differences in the Graduation of Minorities in STEM Fields: Evidence from California." American Economic Review, 2016, 106(3), pp. 525-62; https://doi.org/10.1257/aer.20130626.

Arcidiacono, Peter; Aucejo, Esteban and Spenner, Kenneth. "What Happens after Enrollment? An Analysis of the Time Path of Racial Difference in GPA and Major Choice." IZA: Journal of Labor Economics, 2012, 1(5).

Arcidiacono, Peter and Koedel, Cory. "Race and College Success: Evidence from Missouri." American Economic Journal: Applied Economics, 2014, 6(3), pp. 20-57; https://doi.org/10.1257/app.6.3.20.

Aucejo, Esteban. "Explaining Cross-Racial Differences in the Educational Gender Gap." Working paper, London School of Economics and Political Science, 2012.

Cameron, Stephen V. and Heckman, James J. "The Dynamics of Educational Attainment for Black, Hispanic, and White Males." Journal of Political Economy, 2001, 109(3), p. 455-99; https://doi.org/10.1086/321014.

Carnevale, Anthony P.; Fasules, Megan L.; Andrea, Porter and Landis-Santos, Jennifer. "African Americans: College Majors and Earnings." Policy Report, Center on Education and the Workforce, Georgetown University, 2016.

DeAngelo, Linda; Franke, Ray; Hurtado, Sylvia; Pryor, John H. and Tran, Serge. Completing College: Assessing Graduation Rates at Four-Year Institutions. Higher Education Research Institute, 2011.

Long, Mark C. "Changes in the Returns to Education and College Quality." Economics of Education Review, 2010, 29(3), pp. 338-47; https://doi.org/10.1016/j.econedurev.2009.10.005.

Lynch, Mamie and Engle, Jennifer. "Big Gaps, Small Gaps: Some Colleges and Universities Do Better Than Others in Graduating African-American Students." Education Trust, August 2010.

Sass, Tim R. “Understanding the STEM Pipeline." Working Paper No. 125, CALDER, 2015. 
